Research Paper

\title{
A Study on Bacteriocin Produced from a Novel Strain of Lactobacillus crustorum F11 Isolated from Human Milk
}

SHWETA HANDA* iD and NIVEDITA SHARMA

Microbiology Research Laboratory, Department of Basic Sciences, Dr Y S Parmar University of Horticulture and Forestry, Nauni, Solan 173 230, HP, India

(Received on 31 December 2015; Revised on 29 March 2016; Accepted on 30 March 2016)

\begin{abstract}
Potential probiotic strain of Lactobacillus crustorum F11, isolated from Human milk was studied for the production of bacteriocin. L. crustorum F11 identified by morphological, and biochemical techniques followed by $16 \mathrm{~S}$ rRNA sequencing, NCBI accession number KT865221. Bacteriocin potential of $L$. crustorum F11, studied for the first time, was revealed by strong antagonism against food spoiling and pathogenic bacteria like Staphylococcus aureus, Enterococcus faecalis, Listeria monocytogens, Clostridium perfringens, Leucononstoc mesenteroids and Bacillus cereus. Bacteriocin production was noticed in the late log and beginning of the stationary phase. Bacteriocin was sensitive to proteolytic enzymes like trypsin and proteinase $\mathrm{K}$, thus confirming its proteolytic nature. Bacteriocin activity identified in L. crustorum F11 has a bright prospective for use as food bio-preservative.
\end{abstract}

Key words: Human milk; Lactobacillus crustorum; Bacteriocin; Antagonism

\section{Introduction}

Lactic acid bacteria (LAB) form a phylogenetically diverse group, widely distributed in nature and defined as Gram-positive, non-sporulating, and catalasenegative, devoid of cytochromes, of anaerobic habit but aero-tolerant, fastidious, acid-tolerant and strictly fermentative bacteria that secrete lactic acid as the major end product of sugar fermentation (Pelinescu et al., 2009). Different antimicrobials, such as lactic acid, acetic acid, hydrogen peroxide, carbon dioxide and bacteriocins produced by these bacteria, can inhibit pathogenic and spoilage microorganisms, extending the shelf-life and enhancing the safety of food products (Yukeskdag and Aslim, 2010). One important attribute of LAB is their ability to produce antimicrobial compound called bacteriocin. Bacteriocins are proteinaceous compounds showing inhibition towards sensitive strains produced by both Gram-positive and Gram-negative bacteria (Nomoto, 2005). They have the potential to be used in food and pharmaceutical industries as substitute for chemical preservation (Gao et al., 2010).
Human milk is a complex biological fluid that is species-specific and completely fulfils the nutritional as well as microbiological requirements of the new born. Breast milk boosts immune system and builds body defence against various infectious diseases which makes it superior to other food supplements for infants. Various bioactive compounds like immunoglobulins, lysozyme, antimicrobial acids, oligosaccharides, glycoproteins for example lactoferrin, polyamines, immune cells and bioactive peptides present in breast milk are responsible for its anti-infective effect (Saavedra, 2002; Isaacs, 2005). These bioactive compounds of human milk play a major role in the regulation of the anti-inflammatory system. Human breast milk includes several predominant bacterial species, such as Staphylococci, Streptococci, Micrococci, Lactobacilli, Enterococci, Lacttococci and Bifidobacteria (Albesharat et al., 2011; Gueimonde et al., 2007). Lactobacilli are members of the lactic acid bacteria whose primary fermentation end product is lactic acid. They are commercially important bacteria with a wide variety of application

*Authorfor Correspondence: E-mail: shwetahanda137@gmail.com, niveditashaarma@yahoo.co.in 
both in food and non-food industries due to their "Generally Recognized As Safe" (GRAS) status., Lactobacilli have been extensively studied for their molecular biology with a view to improve their specific beneficial characteristics (Pouwels and Leer, 1993).

This study explores bacteriocin production from a lactic acid bacterial strain isolated from human milk.

\section{Material and Methods}

All chemicals were of analytical grade from Hi-media Laboratories, Mumbai, India. Enzymes used in the study were purchased from Sigma Aldrich, Merck, Bangalore, India.

\section{Source of Culture}

F11 culture was isolated from human milk using the serial dilution and spread plate method on sterilized petriplates containing solidified media Man, Rogosa, Sharpe (MRS) at $37^{\circ} \mathrm{C}$ for $48 \mathrm{~h}$ under anaerobic conditions (Aneja, 2003). Anaerobic conditions were maintained under anaerobic gas jars by using gas pack system (Hi-media, Make). The culture was maintained by biweekly transfers into sterile litmus milk or skim milk medium at $1 \%$ level by inoculating at $37^{\circ} \mathrm{C}$ for $24 \mathrm{~h}$ and held at $-4^{\circ} \mathrm{C}$ between transfers.

\section{Morphological and Biochemical Characteristics}

Color, form, margin, elevation and texture of F11 were recorded. Gram's staining, catalase test, oxidase test, citrate utilization test, gas production from glucose, casein hydrolysis and $\mathrm{H}_{2} \mathrm{~S}$ production and sugar fermentation were performed with isolated strains following standard microbiological techniques (Aneja, 2003). Identification of isolates was carried out using the criteria of Bergey's Mannual of Determinative Bacteriology ( $7^{\text {th }}$ Edn.) (Breed et al., 1957).

\section{Genomic DNA Isolation and PCR Amplification of 16S rRNA Region}

Genomic DNA of F11 was isolated using standard protocol of DNA pre kit (Bangalore Genei, India Pvt. Ltd.). The PCR reaction mix included Taq buffer (10X)-5.0 $\mu \mathrm{l}$; dNTPs-mix $2 \mathrm{mM}-2.5 \mu \mathrm{l}$; primer (F)$10 \mu \mathrm{l}$; Taq polymerase- $2.0 \mu \mathrm{l}$; glycerol $-0.5 \mu \mathrm{l}$; water$12.8 \mu \mathrm{l}$ DNA-1 $\mu \mathrm{l} ; \mathrm{MgCl}_{2}-1 \mu \mathrm{l}$. PCR was carried out with 35 cycles of $92^{\circ} \mathrm{C}$ for $1 \mathrm{~min}, 55^{\circ} \mathrm{C} 1 \mathrm{~min}, 72^{\circ} \mathrm{C} 1$ $\mathrm{min}$. The universal primers used for amplification were
BITS-1 (5'AGAGTTTGATCCTGG) and BITS-4 (5' TACCTTGTTACGACTT) which are expected to generate 1500 bp amplicon. The amplified PCR product was cleaned using the PCR clean-up kit (Real Genomics Hi Yield $^{\mathrm{TM}}$ ). Eluted PCR product of F11 was sequenced by commercial available services of Xceleris, Mumbai, India. The sequence homologies were analysed using the BLAST tool of NCBI (http:/ /www.ncbi.nlm.nih.gov/).

\section{Identification}

On the basis of 16S rRNA sequence, the F11 was identified as Lactobacillus crustorum. The sequences have been deposited at NCBI under the accession number KT865221.

\section{Antimicrobial Activity}

Serious food borne and spoilage-causing bacteria viz., Staphylococcus aureus IGMC, Enterococcus faecalis MTCC 2729, Leucononstoc mesenteroids MTCC 107 and Bacillus cereus CRI were used to study the antagonistic potential. The test strains were procured from Institute of Microbial Technology (IMTECH, Chandigarh, India), Central Research Institute (CRI, Kasauli, H.P. India) and Indira Gandhi Medical College (IGMC, Shimla, H.P. India). All the test strains revived twice for $24 \mathrm{~h}$ at $37^{\circ} \mathrm{C}$ before performing experiments, as all these indicators were preserved in $40 \%$ glycerol at $-20^{\circ} \mathrm{C}$. Antimicrobial activity of isolates was studied by the Bit/Disc method and well diffusion method (Barefoot and Klaenhammer, 1983; Kimura et al., 1998).

\section{Bacteriocin Production During Growth Phase}

$100 \mathrm{ml}$ of MRS broth (pH 6.5 \pm 2 ) was seeded with active bacterial isolate L. crustorum F11 @ 10\% (1.0 OD). Bacterial isolate was incubated in orbital shaker at $35 \pm 2^{\circ} \mathrm{C}$ with a shaking speed of $120 \mathrm{rpm}$ for $90 \mathrm{~h}$. $\mathrm{OD}_{520}$ and bacteriocin production of isolate was detected every $2 \mathrm{~h}$. To detect bacteriocin production, the culture of $L$. crustorum F11 was centrifuged at every $2 \mathrm{~h}$ at $18,000 \mathrm{rpm}$ at $4^{\circ} \mathrm{C}$ for $20 \mathrm{~min}$. The supernatant was filtered and collected in a sterilized test tube. Well diffusion method was repeated with this preparation against indicators $E$. faecalis, $S$. aureus and L. monocytogens. Zone of inhibition was recorded after $2 \mathrm{~h}$. 


\section{Bacteriocin Production}

$100 \mathrm{ml}$ of MRS broth ( $\mathrm{pH} 6.5 \pm 2)$ was seeded with active bacterial isolate L. crustorum F11 @ 10\% (1.0 OD). Bacterial isolate was incubated in orbital shaker at $35 \pm 2{ }^{\circ} \mathrm{C}$ with a shaking speed of $120 \mathrm{rpm}$ for $36 \mathrm{~h}$. The collected supernatant was neutralized to $\mathrm{pH} 7.0$ (with sterilized $1 \mathrm{~N} \mathrm{NaOH}$ ) and catalase was added ( $2 \mathrm{mg}$ in $20 \mathrm{ml}$ ). Further bacteriocin activity in cell free supernatant was determined by activity unit per mililiter (AU/ml) (Kimura et al., 1998; Gautam and Sharma, 2009; Gautam et al., 2014).

\section{Effect of Enzymes - Pepsin, Trypsin, Proteinase $k$ and Protease on the Activity of Bacteriocin}

Effects of proteolytic enzymes on bacteriocin production by $L$. crustorum F11 was checked after neutralizing the effect of acids and $\mathrm{H}_{2} \mathrm{O}_{2}$ with $1 \mathrm{~N}$ $\mathrm{NaOH}$ and Catalase. $0.25 \mathrm{mg}$ of each proteolytic enzymes, viz., pepsin, trypsin, proteinase $\mathrm{K}$ and protease was dissolved separately in $1 \mathrm{ml}$ of $0.5 \mathrm{M}$ phosphate buffer and then added to supernatant in 1:1 ratio. Supernatant, neutralized with $1 \mathrm{~N} \mathrm{NaOH}$ and Catalase, was taken as control. The preparations C, ER1 (crude bacteriocin + pepsin), ER2 (crude bacteriocin + trypsin), ER3 (crude bacteriocin + proteinase $\mathrm{K}$ ) and ER4 (crude bacteriocin + protease) were incubated for $1 \mathrm{~h}$ at $37^{\circ} \mathrm{C}$ and assayed by well diffusion method of Kimura et al., (1998).

\section{Results and Discussion}

\section{Isolation and Identification of Bacteriocin Producer}

Bacteriocin positive isolate $\mathrm{F} 11$ was indentified up to genus level by morphological and biochemical characteristics. Morphologically F11 colonies appeared white and pin pointed on MRS with a smooth texture (Fig. 1). Isolate F11 was found to be catalase and gram positive. It was negative for $\mathrm{H}_{2} \mathrm{~S}$ production.

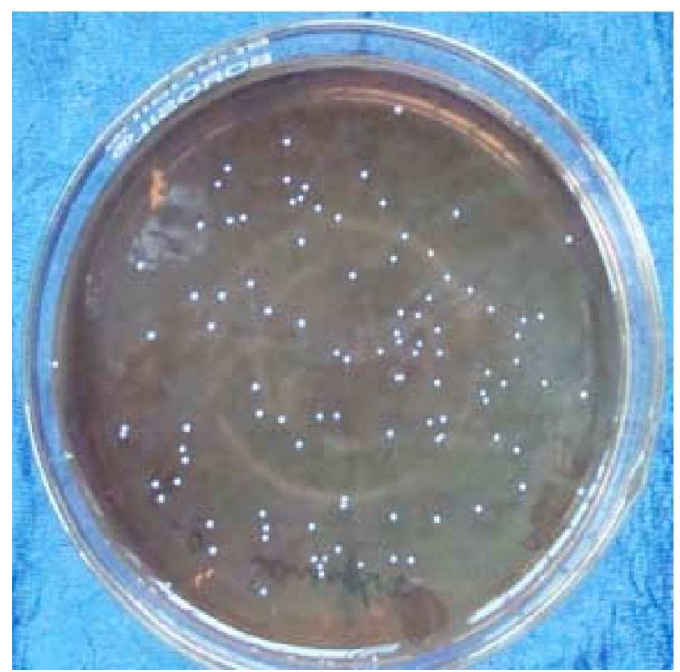

Fig. 1: Morphology of $L$. crustorum F11 on MRS agar

This strain was found to utilize different sugars viz., Sucrose, trehalose, xylose, maltose, lactose and dextrose. On the basis of these characteristics, the F11 was identified as Lactobacillus as per Bergey's Mannual of Determinative Bacteriology (Breed et al., 1957). The identified genus was further identified using 16S rRNA gene technique. The determined sequence of the isolate was compared directly with the Genbank database. A higher level of homology i.e., (96\%) of F11 was observed with sequence of $L$. crustorum. The $16 \mathrm{~S}$ rRNA sequence of $L$. crustorum F11 is registered under accession number KT865221 in NCBI. Phylogenetic tree is presented in (Fig. 2).

\section{Antagonistic Potential}

Antagonistic potential of L. crustorum F11 was tested against selected food borne/spoilage causing bacteria viz., S. aureus IGMC, E. faecalis MTCC 2729, $L$. monocytogens MTCC 839, C. perfringens MTCC 1739, L. mesenteroids MTCC 107 and B. cereus CRI. Data on inhibitory spectrum of the isolate by bit/disc method is shown in Table 1. Among all isolates, $L$.

Table 1: Antagonistic spectrum of $L$. crustorum F11 by Bit disc/well diffusion method in terms of zone size

\begin{tabular}{lcccccc}
\hline Methods & \multicolumn{4}{c}{ Indicators (Foodborne Pathogens) } \\
\cline { 2 - 6 } & S. aureus & E.faecalis & L. monocytogens & C. perfringens & L. mesenteroids & B. cereus \\
\hline Bit disc method & 20.0 & 19.0 & 19.0 & 20.0 & 22.0 & 17.0 \\
Well Difffusion method & 22.0 & 22.0 & 28.0 & 23.5 & 20.0 & 17.0 \\
\hline
\end{tabular}

No. of inhibited indicators

Antagonistic activity in terms of inhibitory zone $(\mathrm{mm})$; Percent inhibition $(\%)=\frac{\text { Total no. of indicators }}{\text {. }}$ 


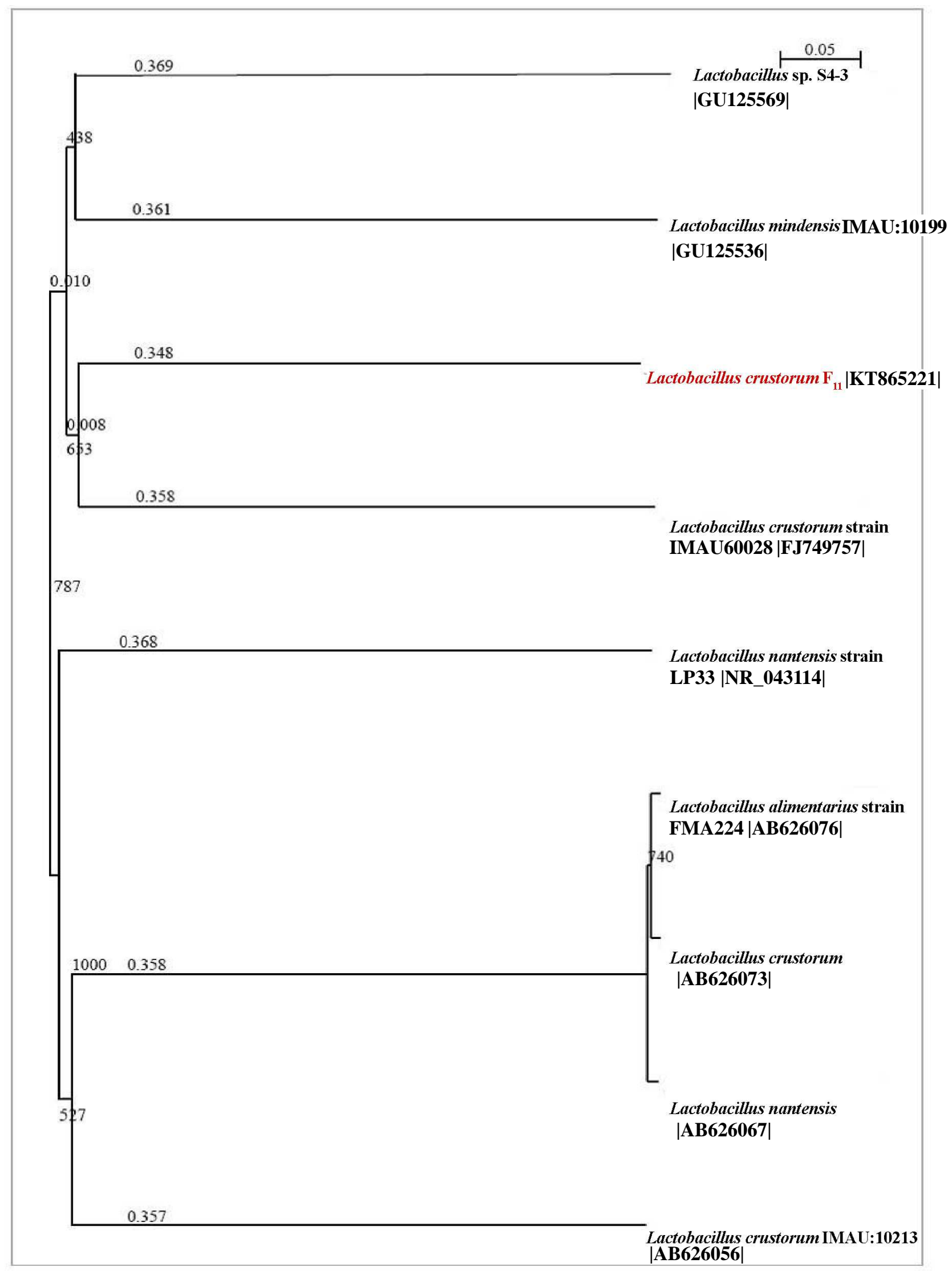

Fig. 2: Phylogenetic tree of Lactobacillus crustorum $\mathbf{F}_{11}$ 


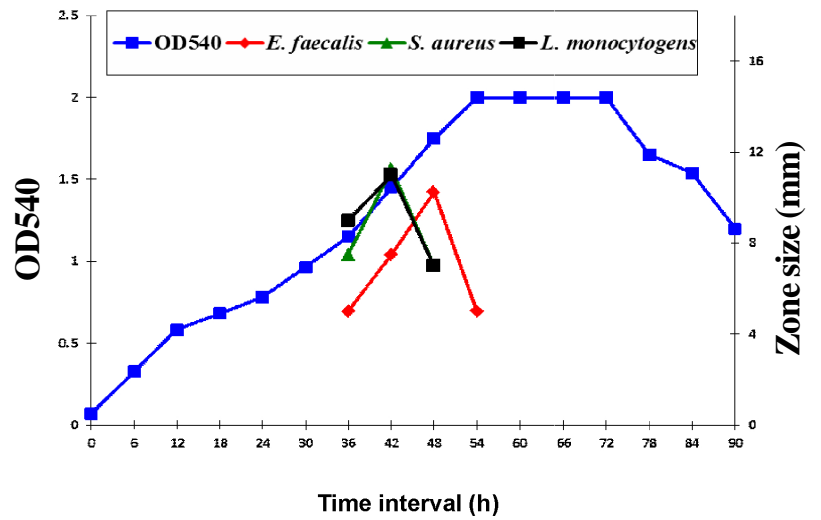

Fig. 3: Inhibitory spectrum of $L$. crustorum $F_{11}$ during its growth phase against three different test indicators

crustorum F11 showed broadest and strongest antagonism ranging from 12-25 $\mathrm{mm}$ against all the test indicators. Therefore, it was selected for further studies. The wide spectrum inhibitory activity against challenging food borne pathogens makes this isolate desirable for exploring its potential for health benefits in production of functional food. Similar studies were reported by Gautam and Sharma, (2015) where Lactobacillus spicheri G2 showed $60 \%$ of antagonism against various test indicators tested by them.

\section{Inhibitory Spectrum of L. crustorum F11 During their Growth Phase}

The growth curve of the isolates, based on the bacterial turbidity level $\mathrm{OD}_{540} \mathrm{~nm}$, followed a sigmoid pattern (Fig. 3). The bacterial cultures were incubated at $37^{\circ} \mathrm{C}$ in MRS broth ( $\mathrm{pH}$ 6.5) for different time intervals (6 to $90 \mathrm{~h}$ ). Optical density and inhibition zones were measured after $6 \mathrm{~h}$ intervals at $540 \mathrm{~nm}$. The growth was initiated at $0 \mathrm{~h}$ with optical density of 0.071 in $L$. crustorum F11. The log phase was between 24 to $42 \mathrm{~h}$ and the stationary phase prevailed between 42 to $78 \mathrm{~h}$. The maximum inhibition against 3 test pathogens taken in the present study (E. faecalis, S. aureus and L. monocytogens) was noticed in the late log phase and in beginning of the stationary phase. The indicated peak period of inhibition was between 42 to $60 \mathrm{~h}$ (OD 1.45 onwards).

The bacteriocin production of L. crustorum F11 was measured on the lawns of indicators i.e. $E$. faecalis (MTCC 2729) after neutralizing the effect of acids and $\mathrm{H}_{2} \mathrm{O}_{2}$ produced by them. The inhibitory activity revealed the presence of bacteriocin produced by the strain. Bacteriocin production, estimated in terms of activity units of culture supernatant, was $2 \times$ $10^{3} \mathrm{AU} / \mathrm{ml}$.

Bacteriocins are proteinaceous compounds or carbohydrate moieties which contribute significantly to inhibit the growth of pathogenic microorganism other than primary metabolites of the isolates. The inhibitory action of LAB is mainly due to accumulation of main primary metabolites such as lactic and acetic acids, ethanol, carbon dioxide; or antimicrobial compounds such as formic, benzoic acids, hydrogen peroxide, diacetyl and acetoin (Yuksekdag and Aslim, 2010). In addition, LAB has shown to possess inhibitory activities due to the bactericidal effect of protease sensitive bacteriocins. By producing these antimicrobial compounds, probiotic microorganisms gain an edge over other microorganisms to survive in the adverse conditions of gastrointestinal tract. Similarly, Gautam et al., (2015) isolated a bacteriocin producing strain Lactobacillus brevis UN from Dulliachar and the strain was found to produce bacteriocin with broad spectrum activity against spoilage causing/food borne pathogens. The maximum bacteriocin production was shown at early stationary phase.

\section{Effects of Enzymes on Bacteriocin}

The effect of proteolytic enzymes was studied on $L$. crustorum $\mathrm{F} 11$ bacteriocin. The proteolytic enzymes decreased bacteriocin activity of $L$. crustorum F11 to 53.2 to $67.2 \%$ as measured by the zone size (Fig. 4).

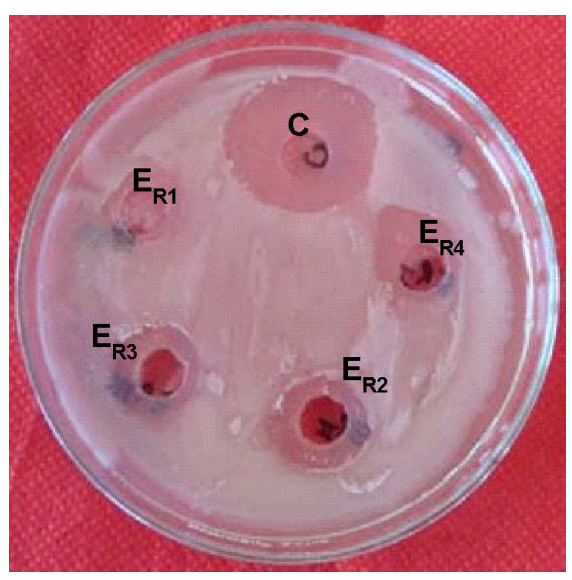

Fig. 4: Effect of different enzymes on the activity of L.crustorum F11 bacteriocin against $E$. faecalis 
Bhattacharya and Dass (2010) also observed that antimicrobial compounds produced by the isolates were inactivated by all the proteolytic enzymes (pepsin and trypsin) whereas no reduction in the zone was encountered when the bacteriocins were treated with amylase, catalase and lipase.

\section{Conclusion}

It may be concluded that bacteriocin synthesised from the first time reported isolate L. crustorum F11 has prospective good potential for use as food preservation since this. bacteriocin is secreted from lactic acid bacteria isolated from human milk and is active against

\section{References}

Albesharat R M, Ehrmann A, Korakli M, Yazaji S and Vogel R F (2011) Phenotypic and genotypic analysis of lactic acid bacteria in local fermented food, breast milk and faeces of mothers and their babies Sys Appl Microbiol 34 148-155

Aneja K R (2003) In: Experiments in microbiology, Plant pathology and Biotechnology. Biochemical activities of microorganisms, 4th edn, New age International Publishers,Barefoot S F and Klanhammer T R (1983) Detection and activity of lactacin B, a bacteriocin produced by Lactobacillus acidophilus Appl Env Microbiol 45 18081815

Bhatacharya S and Dass A (2010) Study of physical and cultural parameters on the bacteriocins produced by Lactic acid bacteria isolated from traditional Indian fermented foods Am J Food Technol 5 111-120

Breed R S, Murray E G D and Smith N R (1957) Bergey's Manual of Determinative Bacteriology, $7^{\text {th }}$ ed., the Williams and Wilkins Co., Baltimore, American Society of Microbiology

Gao Y, Jia S, Gao Q and Tan Z (2010) A novel bacteriocin with a broad inhibitory spectrum produced by Lactobacillus sake $\mathrm{C} 2$, isolated from traditional Chinese fermented cabbage Food Cont 21 76-81

Gautam N and Sharma N (2009) Purification and characterization for purified bacteriocin of Lactobacillus brevis isolated from traditional fermented food of HP Indian J Biochem Biophys 46 337-341

Gautam N and Sharma N (2015) Characterization of bacteriocin producer "Lactobacillus brevis UN" as potential probiotic strain J Microbiol Biotechnol Food Sci 5 216-220

Gautam N and Sharma N (2015) Evaluation of probiotic potential various challenging food borne and spoilage causing pathogens. This renders it completely safe for consumption. Bacteriocins active against pathogens and food spoiling microorganisms are interesting alternatives to chemical preservatives in a variety of industrial applications.

\section{Acknowledgement}

The authors are very thankful to the Department of Basic Sciences, Microbiology section, UHF, Nauni, Solan for providing laboratory facilities and to everyone who contributed to the fulfilment of this study.

of new bacterial strain, Lactobacillus spicheri $\mathrm{G} 2$ isolated from Gundruk Proc Natl Acad Sci 85 979-986

Gautam N, Sharma N and Ahlawat O P (2014) Purification and characterization of bacteriocin produced by Lactobacillus brevis UN isolated from Dhulliachar: a traditional food product of north east India Indian J Microbiol 54 185-189

Gueimonde M, Laitinea K, Salminen S and Isolauri E (2007) Breast milk: a source of bifidobacteria for infant gut development and maturation Neonatol 92 64-66

Isaacs Ce (2005) Human milk inactivates pathogen individually, additively and synergistically $J$ Nutr 51 1286-1288

Kimura H, Sashihara T, Matsusaki H, Sonomoto K and Ishizaki A (1998) Novel bacteriocin of Pediococcus sp. ISK-1 isolated from well-aged bed of fermented rice bran Annals New York Academy Sci 864 345-348

Nomoto K (2005) Prevention of infections by Probiotics. J Biosci Bioeng 100 583-592

Pelinescu D R, Sasarman E, Chifiriuc M C, Stoica I, Nohita A M, Avram I, Serbancea F and Dimov T V (2009) Isolation and identification of some Lactobacillus and Enterococcus strains by a polyphasic taxonomical approach Rom Biotechnol Lett 14 4225-4233

Pouwels P H and Leer R J (1993) Genetics of lactobacilli: Plasmids and gene expression Ant Leeuwen 64 85-107

Saavendra J M (2002) Probiotic agents: clinical applications in infants and children. In: NCR Ra iha“ and FF Rubaltelli (Eds) Infant Formula: Closer to Reference, pp. 15-27. Philadelphia: Lippincott Williams \& Wilkins

Yuksekdag Z N and Aslim B (2010) Assessment of potential probiotic and starter properties of Pediococcus spp. isolated from Turkish-Type fermented sausages (Sucuk) $J$ Microbiol Biotechnol 20 161-168. 